\title{
DIJAGNOSTICIRANJE UZROKA DEGRADACIJE ŠUPLJIH OPEČNIH BLOKOVA UGRAĐENIH U STROPNU ARMIRANOBETONSKU KONSTRUKCIJU
}

\author{
Samo LUBEJ \\ Univerzitet u Mariboru, Fakultet za građevinarstvo, Smetanova ulica 17, 2000 Maribor \\ Boris LUTAR \\ Univerzitet u Mariboru, Fakultet za građevinarstvo, Smetanova ulica 17, 2000 Maribor
}

Sažetak: U konstrukciji montažnih stropova od šupljih opečnih blokova, koji su element ispune između nosivih armiranobetonskih greda, u razdoblju od četiri godine poslije njihove izgradnje došlo je do znatnih oštećenja. Oštećenja stropova manifestirala su se odlamanjem dijelova šupljih opečnih blokova, što je ugrožavalo sigurnost ljudi. Uporabom optičkog mikroskopa i elektronskog mikroskopa, kao i kemijske mikroanalize EDS (Energy Dispersive System), analizirana je oštećena keramika te je utvrđena prisutnost iskristalizirane soli. EDS analizom utvrđena je prisutnost kemijskih elemenata (Al i S), koji uz utvrđenu morfologiju kristala ukazuju na mogućnost prisutnosti minerala etringita $\left(\mathrm{Al}_{2} \mathrm{O}_{3} 3 \mathrm{CaSO}_{4} \times 32 \mathrm{H}_{2} \mathrm{O}\right)$. Numeričkom analizom uz primjenu metode konačnih elemenata, uporabom računalnog programa COSMOS Design STAR 3.0 od SRAC (Structural Research and analisis Corporation USA), procijenjen je utjecaj temperaturnih opterećenja na koncetraciju naprezanja na vrhu mikropukotina i na njihovo širenje. U numeričkoj analizi eksperimentalno su uzeta u obzir određena fizikalnomehanička svojstva materijala. Analizirani su primjeri šupljih opečnih blokova s prisutnošću bijelih kristala i bez njih. Prikazan je raspored faktora sigurnosti po modelu u odnosu na Mises-ovu hipotezu razaranja. Rezultati eksperimentalnih i numeričkih istraživanja pokazali su da kemijska degradacija šupljih opečnih blokova, u kombinaciji s temperaturnim opterećenjem koje nastaje zbog promjena klimatskog režima, može uzrokovati takva oštećenja te da je time ugrožena i sigurnost konstrukcije.

Ključne riječi: šuplji opečni blokovi, mikrostruktura, zakašnjelo stvaranje entringita (DEF), mehanička svojstva, toplotna analiza

\section{DIAGNOSING THE CAUSES OF CLAY HOLLOW BRICKS DEGRADATION EMBEDDED IN THE REINFORCED CONCRETE CEILING}

\begin{abstract}
Over a two-year period following the construction completion extensive damage has occurred in the mountable brick ceilings at the University of Maribor administrative quarters. The damage of the ceilings consisted in falling pieces of brick filling - construction ceramics, which presented a potential hazard to people. Using the optical as well as electronic microscope methods combined with chemical analysis EDX (Energy Dispersive X-Ray Analysis) we confirmed the presence of the white crystals, which could be mineral ettringite $\left(\mathrm{Al}_{2} \mathrm{O}_{3} 3 \mathrm{CaSO}_{4} \times 32 \mathrm{H}_{2} \mathrm{O}\right)$ that can, when present in construction ceramics, cause degradation of matter through expansion. By means of numerical analysis using final elements method and by means of the COSMOS Design STAR 3.0 computer software (by SRAC - Structural Research and Analysis Corporation USA) we were able to experimentally determine effects of temperature fluctuation. The experimentally assessed physical-mechanical characteristics of the material were considered in the numerical analysis. Both cases, brick filling containing the white crystals and brick filling without white crystals were analysed. The safety factor distribution on the model according to Mises demolition hypothesis was shown. It was confirmed on basis of experimental research that the chemical degradation of construction ceramics combined with temperature fluctuation due to climate changes, even without considering degradations due to technological production process, can lead to such damage in the material as to cause a safety hazard.
\end{abstract}

Key words: clay hollow bricks, mycrostructure, delayed ettringite fomation (DEF), echanical properties, thermal analysis 


\section{Uvod}

Građevinska keramika predstavlja keramičke proizvode koji se upotrebljavaju u građevinarstvu. U tehnološkom procesu proizvodnje kao osnovna sirovina upotrebljava se opekarska glina. U glinama su obično u obliku primjesa prisutni i sulfati, a prije svega gips. Gips je u vodi topiva sol i nepoželjan je u građevinskoj keramici, jer uzrokuje izlučivanje topivih minerala koji kod keramičkih proizvoda uzrokuju mehaničko razaranje materijala. U tehnološkom procesu izrade građevinske keramike opekarskoj glini se dodaju i dodatci kojima se snižava temperatura pečenja. Dodaje se prije svega vapno koje sadrži i primjese. Vapnena zrna koja su primiješana opekarskoj glini se pri pečenju gline promijene u negašeno vapno koje za sebe veže vlagu i pretvara se u gašeno vapno. Na mjestima većih koncetracija gašenog vapna u građevinskoj keramici, zbog utjecaja vlage poveća se volumen materijala, što uzrokuje mikropukotine i razaranje materijala. Poznato je također da vapneni minerali mogu materijal i učvrstiti kao što je to evidentno kod stijena od škriljavca, ali ova karakteristika odmah se pogoršava ako dolazi do cikličkog vlaženja i sušenja [1]. U biti, za građevinsku keramiku kao materijal vrijedi da prisutnost ili odsutnost karbonata vrlo bitno utječe na razvoj poroznosti, na teksturu i fizikalno-mehanička svojstva. Karbonati u sirovoj glini uzrok su nastanka mikropukotina i pora, ali njihova odsutnost nužno smanjuje poroznost te podiže temperaturu pečenja [2]. Poroznost je vrlo bitna karakteristika građevinske keramike koja utječe najčešće na: kemijsku reaktivnost, čvrstoću, trajnost i opću kakvoću.

Količina i raspodjela pora ovisi o kakvoći gline, prisutnim aditivima, nečistoćama i temperaturi pečenja. Uz višu temperaturu pečenja povećava se udio pora veličine od 3 do $15 \mu \mathrm{m}$, smanjuje se međusobna povezanost tih pora i isto tako se smanjuje udio pora manjih od $3 \mu \mathrm{m}$. Takav tip poroznosti ima bitan utjecaj na trajnost opeke. Također je bitno da pore nisu međusobno povezane, jer kod takve opeke nema rizika od štetnog djelovanja u vodi otopljenih soli. U građevinarstvu je poznat primjer cvjetanja soli koji je izrazito estetskog karaktera, dok kristalizacija soli može uzrokovati ozbiljne degradacije [3]. Za opeku kao građevinski materijal poznato je da je prisutnost vapnenih minerala bitno povezana sa svojstvom vodoupojnosti i otpornosti na mraz. Vrijedi pravilo da u vodi topive soli pogoršavaju otpornost opeke na djelovanja cikličkog smrzavanja i odmrzavanja [4]. U građevinarstvu je poznata sulfatna korozija opeke i hidratizirani mort. Obično se ova kemijska reakcija dogodi na spoju ovih materijala, kada u vodi otopljeni sulfati reagiraju s trikalcij-aluminatom kojega ima u portland cementu. Produkt ove reakcije je mineral etringit-trikalcij sulfoaluminat hidrat [5]. Sulfati mogu biti prisutni u opeci zbog tri razloga:

- mogu penetrirati iz okoline zbog zagađenja zraka $\mathrm{Sa} \mathrm{SO}_{2}$

- mogu biti već prisutni u opeci njačešće zbog pečenja na nižim temperaturama, također mogu biti prisutni u sirovini i mogu se pojaviti ako ih ima u energentu koji se koristi za pečenje

- mogu penetrirati s transportom vode po kapilarama [3], [6].

$\mathrm{U}$ vodi rastopljene soli, koje se po materijalu transportiraju vlagom, uzrokuju pogoršanje karakteristika materijala i degradaciju opečnih konstrukcija. Do pogoršanja mehaničkih karakteristika dolazi zbog kristalizacije u vodi rastopljenih soli - najprije sulfata koji uzrokuju raspadanje materijala na nivou mikrostrukture $[5,7]$. Ako su u mortu koji je u neposrednoj blizini opeke prisutni sulfati, oni mogu u dužem vremenskom periodu izazvati sulfatnu koroziju [8]. Do takvih pojava može doći samo u vlažnoj okolini, gde je prisutna voda zasićena sulfatima natrija i kalija [7]. Poznato je da se sulfatni ioni iz betona ili morta mogu po kapilarama transportirati i u porozne dijelove opeke [5]. Manje je poznato da primjese u dodanim otopljivačima mogu prouzročiti i stvaranje minerala etringita koji poslije određenog vremena, u povoljnim uvjetima kao što su naprimjer visoka vlažnost i temperatura, također uzrokuje degradaciju materijala. Mineral etringit nastaje uz potrebne uvjete. Materijal mora imati dovoljno velike prostore za nastanak kristala i sadržavati dovoljno vode. Rastom igličastih kristala troši se voda i kristali ispune prostor koji je u materijalu zauzimala voda. Fenomenološki dokaz nastanka etringita je prisutnost sulfata. Reakcija nastanka etringita nije topokemijska. Poznato je da su mogući razlozi kemijske degradacije zidanih konstrukcija alkalno-amorfne silikatne reakcije u kamenim agregatima, a također i sulfatne reakcije koje mogu izazvati rast kristala etringita [3], [15]. Mineral etringit se formira zbog vapna i cementa u alkalnoj okolini, gde uz prisutnost vlage dolazi do reakcije sa sulfatima i aluminatima [9]. Kako je volumen kristala etringita veći od volumena reaktanata, može uzrokovati u strukturi keramičkih proizvoda, koji su porozni i imaju mikropukotine, povećanje mikropukotina koje se zbog temperaturnog djelovanja konstrukcije postepeno povećavaju u pukotine. Povećavanje i spajanje mikropukotina u pukotine lokalno veoma oslabi presjek keramičnog proizvoda. Moguće je 
da se zbog utjecaja lokalnih vlačnih naprezanja pojave i krti prijelomi koje smo utvrdili na primjeru proučavane konstrukcije, montažnih ploča iz građevinske keramike - šupljeg opečnog bloka.

$\mathrm{Na}$ stropnoj konstrukciji, u koju su među armiranobetonskim nosačima bila ugrađena punila od šupljeg opečnog bloka, četiri godine poslije ugradnje utvrđena su znatna oštećenja. Ugrađen šuplji opečni blok u stropu bio je oštećen - napukao. Spajanje pukotina u zoni naprezanja stropne konstrukcije na nekim mjestima je uzrokovalo otpadanje dijelova šupljeg opečnog bloka. Primjer takvog oštećnja prikazan je na slici 1.

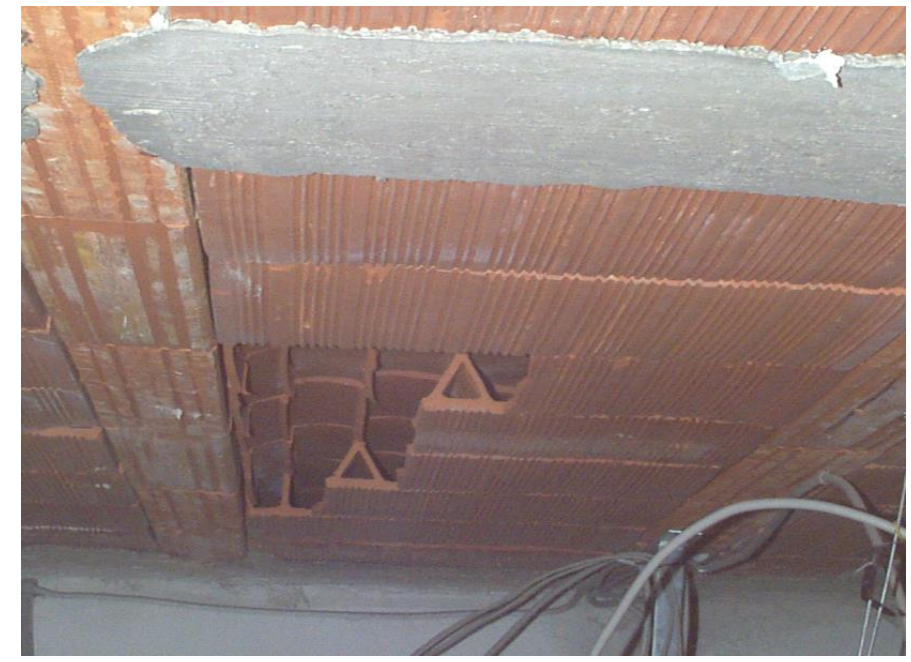

Slika 1 - Tipično oštećenje na stropu

Svrha ovog istraživanja je utvrditi utjecaj kvalitete materijala i temperaturnih opterećenja na uočena oštećenja na objektu. Oštećenja šupljih opečnih blokova počela su se pojavljivati četiri godine poslije ugradnje i to u vrijeme prve sezone grijanja - objekt tri godine nije bio useljen.

\section{Materijali i metode}

Konstrukcija stropa bila je izvedena kao klasična pločasta brana. Nosivost stropne konstrukcije izvedena je $35 \mathrm{~cm}$ visokim armiranobetonskim nosačima u oba pravca i čeličnim nosačima u sustav koji povezuje $7 \mathrm{~cm}$ debela armiranobetonska ploča. Da bi se osigurala što manja masa stropa, bili su upotrijebljeni laki elementi - šuplji opečni blok, na koji je za vrijeme ugradnje nalijepljena toplinska izolacija iz ekspandiranog polistirena. Primjer sustava izvedene stropne konstrukcije dan je na slici 2.

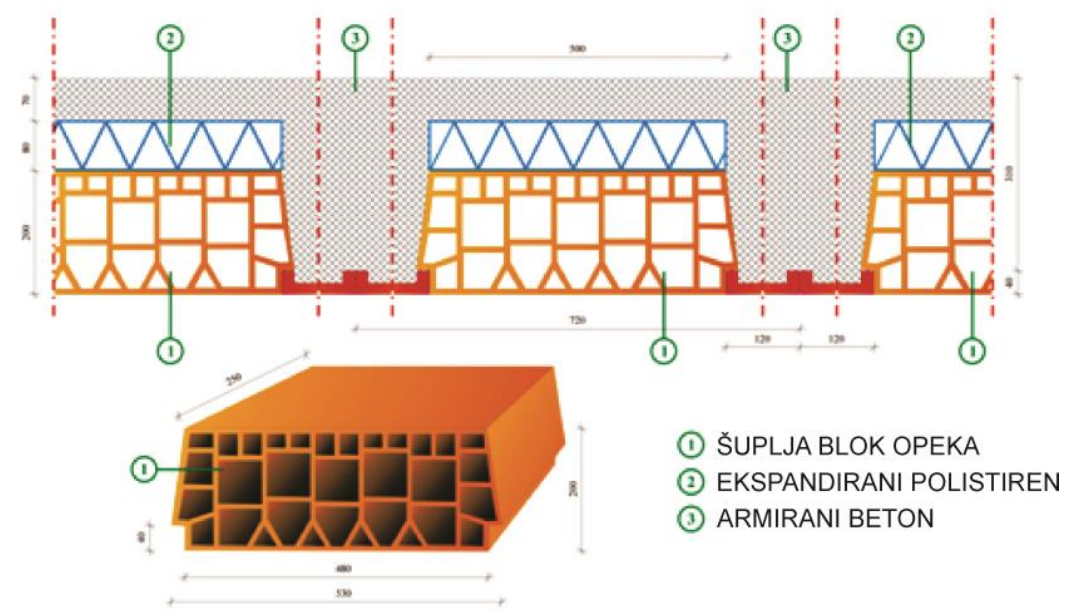




\section{Slika 2 - Primjer izvedene stropne konstrukcije}

Pukotine su se pojavile na najznačajnijim mjestima, po pravilu na donjim površinama ugrađenih šupljih opečnih blokova. Detaljan pregled konstrukcije je pokazao da nosivi elementi stropne konstrukcije, armiranobetonski nosači, nisu deformirani i raspukli. Mjerenje deformacija stropnih konstrukcija na mjestu maksimalnih opterećenja pokazalo je da na konstrukciji nema povećanih deformacija zbog uleknuća stropa, odnosno relativnih pomicanja među nosećim elementima stropa. Prvobitna sumnja da je uzrok nastale štete pogrešan proračun nosivosti stropa, isključena je kontrolom statičke procjene. Uzroci pojava oštećenja analizirani su obimnim istraživanjima. Na terenu su uzeti uzorci materijala i izrađeno je geodetsko snimanje mjerenjem deformacija konstrukcije. Standardnim proučavanjem uzoraka cijelih šupljih opečnih blokova, u laboratoriju je izmjereno upijanje vode i utvrđena karakteristična tlačna čvrstoća. Pregled mikrostrukture materijala - uzoraka uzetih iz objekta na mjestu oštećenja, izvršen je optičkim i elektronskim mikroskopom. Također je elektronskim mikroskopom izvršena i kemijska analiza EDS (Energy Dispersive System). Ispitivanje je prije svega usmjereno na kontrolu kvalitete materijala - šupljih opečnih blokova, zapravo čitavog neporušenog sustava betonske ploče s elementima ispune od šupljih opečnih blokova koje iz stropa nije bilo moguće uzeti. Uzorci su uzeti od dijelova šupljih opečnih blokova s pukotinama i bez njih. Pokusom je utvrđeno da se na dijelovima uzorka koji su imali pukotine, na nekim mjestima prijelomnih površina pojavljuju kristali bijele boje. Izgled takve prijelomne površine daje slika 3.

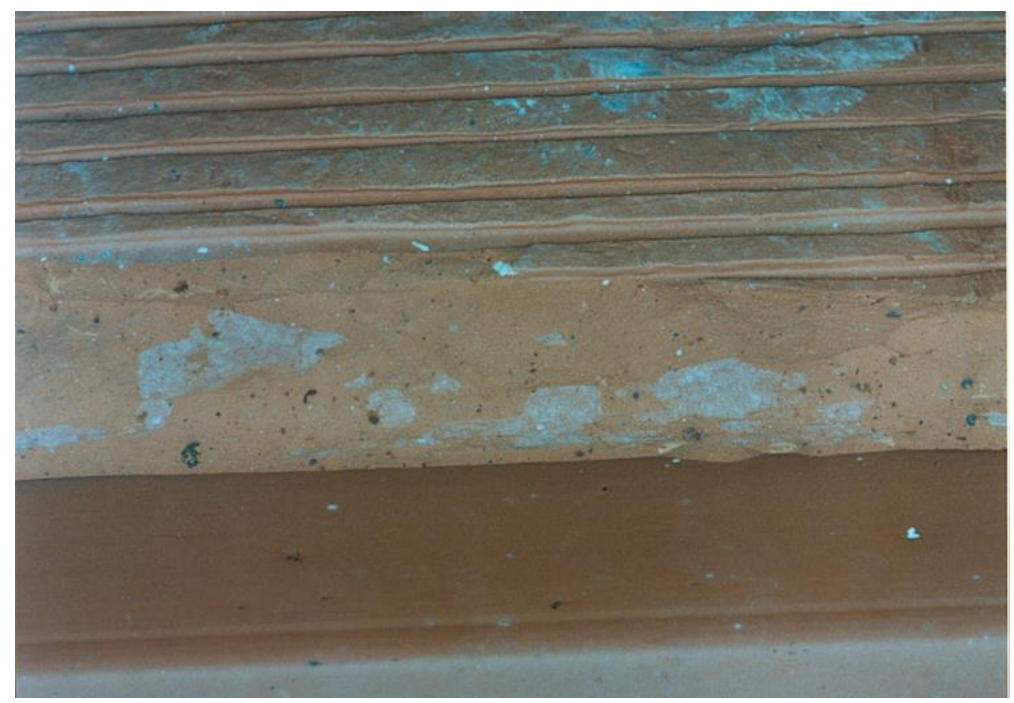

\section{Slika 3 - Prijelomna površina uzorka šupljeg opečnog bloka s kristalima bijele boje}

Na uzetim uzorcima dijelova šupljeg opečnog bloka izmjereno je upijanje vode, vlačna čvrstoća i modul elastičnosti. Upijanje vode je kod građevinske keramike važan podatak koji pokazuje usporednu vrijednost proizvoda u građevinarstvu. Za građevinsku keramiku podrazumijevamo keramičke proizvode koji upijaju između 8 i $20 \%(\mathrm{~m} / \mathrm{m})$ vode. Upijanje vode je osobina koja ovisi o otvorenoj poroznosti materijala [10]. Upijanje vode za ispitane uzorke utvrđeno je gravimetrijskom metodom. Uzorci su uronjeni u demineraliziranu vodu do maksimalnog zasićenja, zatim sušeni u laboratorijskoj sušionici do konstantne mase na temperaturi $100 \pm 5^{\circ} \mathrm{C}$.

Uzorci za mjerenje mehaničkih svojstava materijala pripremljeni su iz dijelova šupljih opečnih blokova bez pukotina i bez tragova bijelih kristala na prijelomnim površinama (oznaka uzorka je A1), s tragovima bijelih kristala na prijelomnim površinama (oznaka uzorka B2) i iz slučajno izabranog dijela šupljih opečnih blokova (oznaka uzorka je C3). Modul elastičnosti i razorne vlačne čvrstoće utvrđeni su tako da su uzorci opterećeni vlačnom silom koja je narastala konstantnom brzinom $0,5 \mathrm{~mm} /$ minuti u laboratorijskim klimatskim uvjetima. Za mjerenja je upotrijebljena univerzalna hidraulična kidalica INSTRON 1255.

Prijelomne površine uzorka šupljih opečnih blokova iz objekta pregledane su optičkim stereo mikroskopom OLYMPUS SZX 12 i elektronskim mikroskopima JEOL 840A, JEOL JSM 5610, QUANTA 200 3D, odnosno 
SIRON 400 NC. Promatrane su prijelomne površine s kristalima bijele boje. Svrha promatranja bila je prije svega utvrditi morfologiju kristala koji se pojavljuju na nekim prijelomnim površinama i njihov kemijski sastav. Za izradu kemijske analize (EDS) upotrijebili smo elektronski mikroskop SIRION 400 NC i JEOL JSM 5610.

Budući da je pretpostavljeno da su oštećenja nastala i zbog temperaturnog djelovanja konstrukcije, izrađeni su proračuni temperaturnih opterećenja šupljih opečnih blokova dimenzija 250 × $475 \times 200 \mathrm{~mm}$. U proračun je uzeto u obzir da je vrijednost temperature na donjoj površini stropa $30^{\circ} \mathrm{C}$, a na gornjoj površini ta vrijednost iznosi $14^{\circ} \mathrm{C}$. Ove vrijednosti uzete su temeljem izvršenih mjerenja klimatskih uvjeta na objektu. Opterećenja na šuplje opečne blokove i njihova vlastita težina nije uzeta u obzir, jer je u prethodnim proračunima utvrđeno da je taj utjecaj beznačajan. Izračunavanja su bila izvedena po metodi konačnih elemenata programom COSMOS DesignSTAR 3.0 od SRAC (Structural Research and Analysis Corporation) [11]. Ovaj program omogućava izradu podataka za kontrolno izračunavanje programima PATRAN, ANSYS, IDEAS i drugim.

Prilikom izrade geometrijskog modela šupljeg opečnog bloka opeke uzeta je za debljinu stijenke vrijednost 8 $\mathrm{mm}$, iako su stvarne debljine zidova na pojedinim mjestima i manje. U proračunu su uzeta u obzir laboratorijski određena fizikalno-mehanička svojstva materijala. Za vrijednost koeficijenta linearnog temperaturnog rastezanja (a) uzeto je $5,0 \times 10^{-6} \mathrm{~K}^{-1} \mathrm{i}$ to na temelju podataka iz literature [12]. Treba napomenuti da vrijednost ovog koeficijenta bitno utječe na rezultate, kao i debljina zidnog modela koja je inače u prosjeku veća od stvarnog prosjeka stijenki šupljih opečnih blokova.

U proračunima također nisu uzete u obzir mikropukotine na stijenkama šupljih opečnih blokova, iako su one stvarno uvijek prisutne zbog tehnološkog procesa njihove izrade. $U$ tom bi se slučaju prikazane izračunate vrijednosti još povećale. Za elemente promatranog geometrijskog modela izabrani su prostorni parabolični elementi s prosječnom veličinom stranica $4 \mathrm{~mm}$ i ravnomjerni način mreženja. Zbog simetrije geometrijskog modela bilo je moguće promatrati jednu četvrtinu jednog elementa šupljeg opečnog bloka. Promatrani model ima 42163 čvorišta, 169346 elemenata i 845208 linearnih algebarskih jednadžbi.

\section{Rezultati i rasprava}

\subsection{Određivanje upijanja vode}

Izmjerene vrijednosti upijanja vode za uzorke šuplijh opečnih blokova kod kojih su na prijelomnim površinama uočeni kristali bijele boje i za one na kojima kristala nema, dani su u tablici 1. Prosječna vrijednost upijanja vode za uzorke s tragovima kristala bijele boje iznosila je 17,7\% (m/m), a za uzorke bez tragova 16,9 \% (m/m).

Tablica 1 - Vrijednosti upijanja vode $\left(w_{t}\right)$ za uzorke (1 do 5 ) s tragovima kristala bijele boje i za uzorke (I do V) bez tragova kristala bijele boje na prijelomnim površinama

\begin{tabular}{|c|c|c|c|}
\hline uzorak & $\mathrm{W}_{\mathrm{t}}(\% \mathrm{~m} / \mathrm{m})$ & uzorak & $\mathrm{W}_{\mathrm{t}}(\% \mathrm{~m} / \mathrm{m})$ \\
\hline \hline 1 & $16,5(\mathrm{~min})$ & $\mathrm{I}$ & $15,8(\mathrm{~min})$ \\
\hline 2 & 17,8 & $\mathrm{II}$ & 17,0 \\
\hline 3 & 17,6 & $\mathrm{III}$ & 17,6 \\
\hline 4 & 18,0 & $\mathrm{IV}$ & $18,3(\mathrm{max})$ \\
\hline 5 & $18,5(\mathrm{maks})$ & $\mathrm{V}$ & 15,8 \\
\hline
\end{tabular}

Laboratorijskim analizama utvrđeno je da je na uzorcima na kojima ima igličastih kristala u prosjeku veće upijanje vode nego na uzorcima gdje tih kristala na površini nema.

\subsection{Određivanje modula elastičnosti}

Na osnovi krivulja $\sigma / \varepsilon$ izračunan je modul elastičnosti E. Vlačna čvrstoća pojedinog uzorka određena je temeljem izmjerene sile prilikom prijeloma uzorka. Karakteristične vrijednosti za modul elastičnosti $E$ i vlačna čvrstoća dane 
su u tablici 2. Inženjerska vlačna čvrstoća $R_{m}$, uz uvažavanje nominalne prijelomne površine uzorka, a reducirana vrijednost $R_{m}{ }^{*}$ izračunana je uz djelomično uzimanje u obzir kose prijelomne površine uzorka.

Tablica 2 - Karakteristične vrednosti za modul elastičnosti $(E)$ i natezna čvrstoća $\left(\mathbf{R}_{m}\right)$

\begin{tabular}{|c|c|c|c|c|}
\hline Uzorak & $\mathrm{F}_{\max }(\mathrm{kN})$ & $\mathrm{E}(\mathrm{MPa})$ & $\mathrm{R}_{\mathrm{m}}(\mathrm{MPa})$ & $\mathrm{R}_{\mathrm{m}}{ }^{*}(\mathrm{Mpa})$ \\
\hline \hline $\mathrm{A} 1$ & 1,45 & 22203 & 7,9 & 6,8 \\
\hline $\mathrm{B} 2$ & 1,95 & 44270 & 13,8 & 13,6 \\
\hline $\mathrm{C} 3$ & 1,57 & 40879 & 8,5 & 6,9 \\
\hline
\end{tabular}

\subsection{Pregled prijelomnih površina uzoraka mikroskopom}

Prvo su optičkim mikroskopom pregledane prijelomne površine s kristalima bijele boje. Ustanovljeno je da su kristali igličastog oblika i da se pojavljuju u grupama. Izgled je prikazan na slici 4.

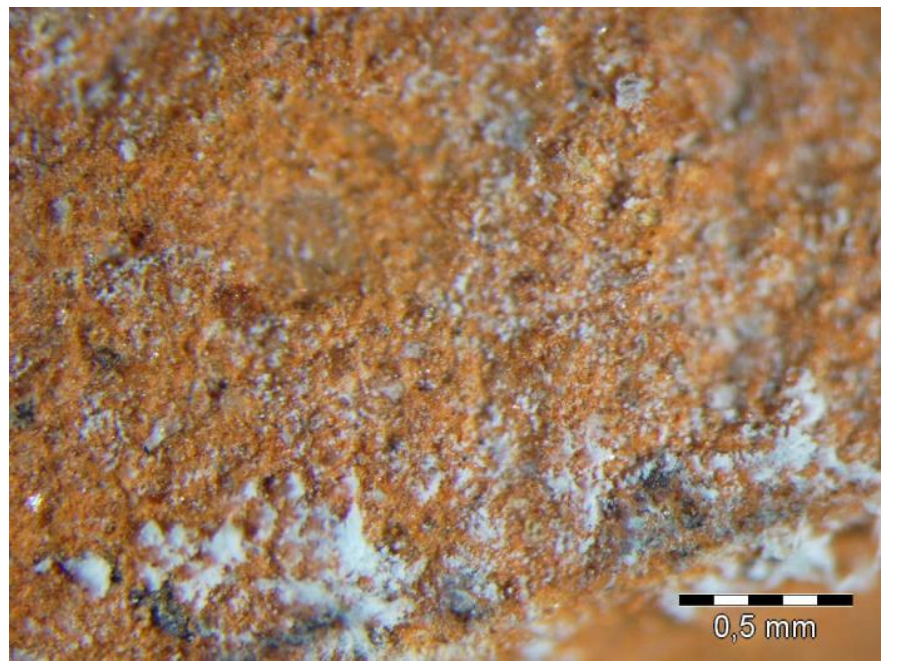

Slika 4 - Fotografija kristala pregledanih optičkim mikroskopom

Svrha pregleda bila je prije svega utvrditi morfologiju kristala koji se pojavljuju na nekim prijelomnim površinama i njihov kemijski sastav. Za pregled su pripremljena tri uzorka koja su imala na površini tragove bijelih kristala i jedan uzorak s čistom prijelomnom površinom. Rezultati pregleda elektronskim mikroskopom, koji pokazuju morfologiju kristala i čistu prijelomnu površinu bez kristala, dani su na slikama 5a), 5b) i 6a), 6b). Slika 7a) prikazuje polje kristala na kojima su izvršene mikrokemijske analize u točki, a na slikama 7b), 7c) i 7d) dani su rezultati tih analiza. Na slici 8a) prikazan je spektar površine s kristalima na kojima je izvršena kemijsku analizu EDS. Rezultat kemijske analize EDS dan je na slici 8b). 


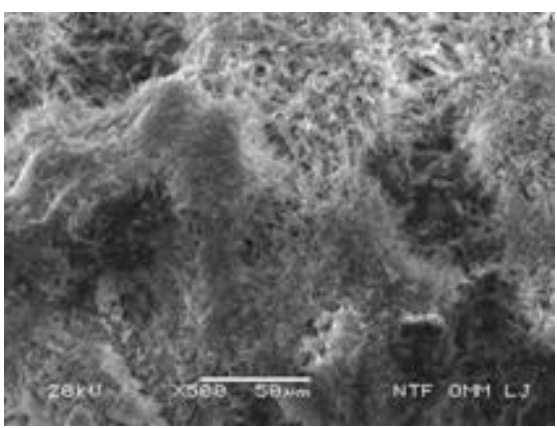

5a) - Mikrograf (SEM, SEl s JEOL JSM 5610)povećanje $\mathbf{5 0 0}$ puta, površina s kristalima

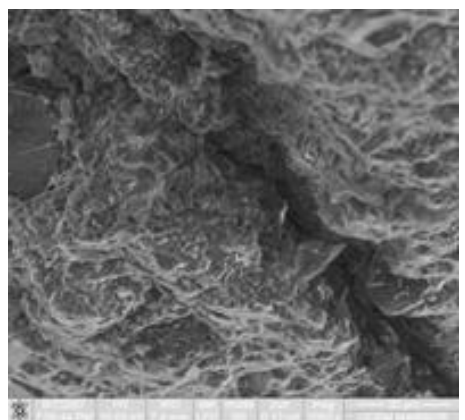

Slika 6a) - Mikrograf (SEM, SEI s QUANTA 200 3D) - povećanje 1000 puta, površina bez kristala

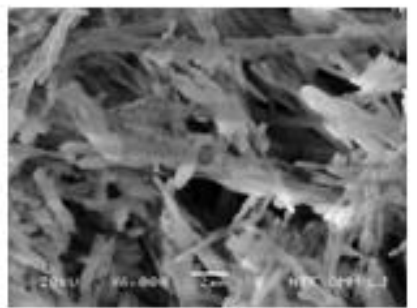

a)

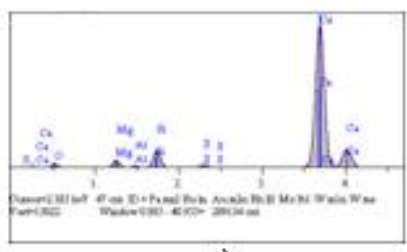

c)

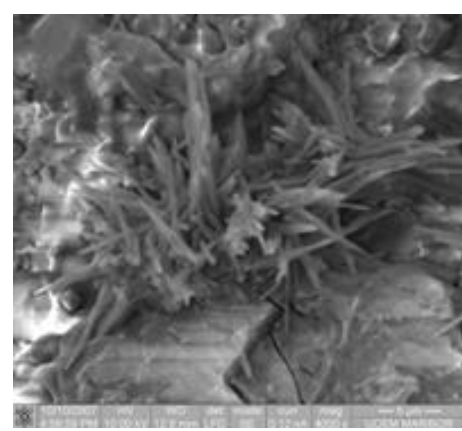

Slika 5b) - Mikrograf (SEM, SEI s QUANTA 200 3D), povećanje 4000 puta, površina s kristalima

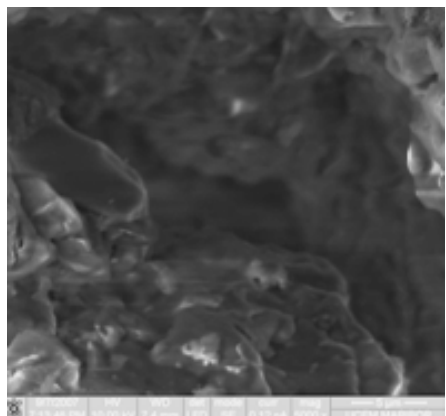

Slika 6b) - Mikrograf (SEM, SEI s QUANTA 200 3D) - povećanje 5000 puta, površina bez kristala

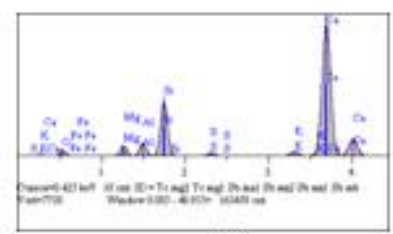

b)

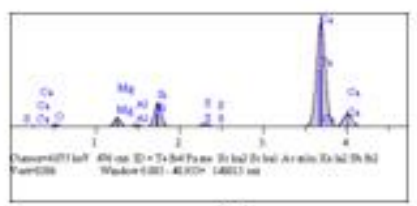

d)

Slika 7 - a) SEM, SEl mikrograf kristala s JEOL JSM 5610, b), c) i d) EDS analiza u točki na kristalu 


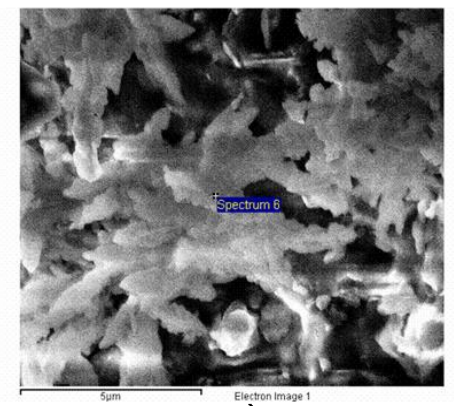

a)

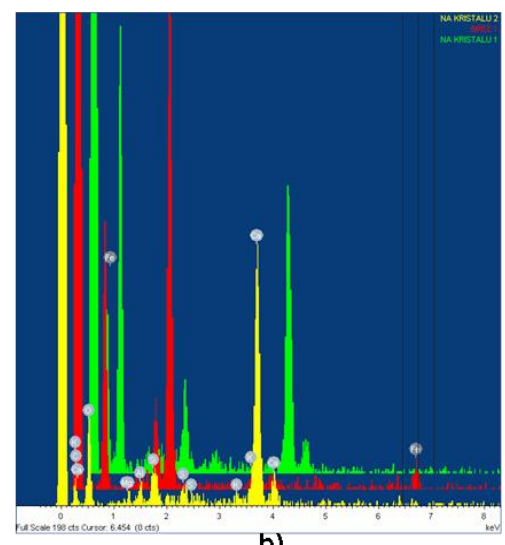

b)

Slika 8a) - Mikrograf (SEM, SEI s SIRION 400 NC) spektra površine kristala za kemijsku analizu (EDS); b) Rezultat kemijske analize (EDS)

Iz fotografija prijelomne površine na kojima su prisutni bijeli kristali, pri povećanju 1000 i 5500 puta jasno je da su igličasti kristali po površini raspoređeni neravnomjerno. EDS analizom smo ustanovili prisutnost kemijskih elemenata $\mathrm{C}, \mathrm{O}, \mathrm{Mg}, \mathrm{Al}, \mathrm{Si}, \mathrm{S}, \mathrm{K}, \mathrm{Cu}$, i Fe. EDS analiza uzorka s čistom prijelomnom površinom ukazuje na ravnomjernu prisutnost elementa $\mathrm{O}$ po čitavoj površini, elementi Al i S su prisutni u jedva mjerljivoj količini. Linijska EDS analiza uzorka sa stvaranjem igličastih kristala pokazuje jaku oscilaciju elemenata S i Ca na mjestima kristala. Prisutnost Si na tim mjestima praktično je vrlo mala, prisutan je samo na mjestu gde nema kristala. Rezultate EDS analize spektra sa slike 8a) numerički su prikazani u tablici 3, a u tablici 4 dani su rezultati EDS analize na pojedinim kristalima sa slike $7 a)$.

Tablica 3 - Rezultati EDS analize mikroskopom SIRION NC 400 dani su u masenim \%

\begin{tabular}{|l|c|c|c|c|c|c|c|c|c|}
\hline Spektar & $\mathbf{C}$ & $\mathbf{0}$ & $\mathbf{M g}$ & $\mathbf{A l}$ & $\mathbf{S i}$ & $\mathbf{S}$ & $\mathbf{K}$ & $\mathbf{C a}$ & $\mathbf{F e}$ \\
\hline Na kristalu & 13.67 & 58.60 & 0.33 & 0.92 & 2.73 & 0.49 & 0.69 & 22.56 & \\
\hline Bez kristala & & 41.69 & & 5.34 & 37.81 & & & & 15.17 \\
\hline Na kristalu & 2.40 & 43.07 & 1.14 & 1.37 & 2.92 & 2.17 & 1.22 & 45.71 & \\
\hline Maksimalno & 13.67 & 63.28 & 1.14 & 5.34 & 37.81 & 2.17 & 1.22 & 45.71 & 15.17 \\
\hline Minimalno & 2.40 & 41.69 & 0.33 & 0.92 & 2.73 & 0.49 & 0.69 & 20.68 & 15.17 \\
\hline
\end{tabular}

Tablica 4 - Rezultati EDS analize mikroskopom JEOL JSM 5610 dani su u masenim \%

\begin{tabular}{|l|c|c|c|c|c|c|c|c|c|}
\hline Spektar & $\mathbf{C}$ & $\mathbf{0}$ & $\mathbf{M g}$ & $\mathbf{A l}$ & $\mathbf{S i}$ & $\mathbf{S}$ & $\mathbf{K}$ & $\mathbf{C a}$ & $\mathbf{F e}$ \\
\hline Na kristalu & - & 15,7 & 3,4 & 3,9 & 15,9 & 1,1 & 1,6 & 54,8 & 3,6 \\
\hline Na kristalu & - & 16,3 & 3,2 & 0,7 & 6,0 & 1 & - & 72,8 & - \\
\hline Na kristalu & - & 13,4 & 4,9 & 1,2 & 10,7 & 1,5 & - & 68,3 & - \\
\hline
\end{tabular}

Istraživanja mehaničkih osobina pokazala su veliku rasutost rezultata, što potvrđuje opća svojstva za keramičke materijale koji su strukturno heterogeni, porozni i krhki. Osnovna sirovina za izradu šupljih opečnih blokova je "opekarska glina" koja sadrži relativno malu količinu kaolinita i mnogo drugih primjesa, kao na primer kvarc, spojeve željeza i kalija. Na prijelomnim površinama na kojima su prisutni igličasti kristali utvrđen je kemijski element sumpor. Na temelju izvršene kemijske analize i utvrđene izrazito igličaste strukture kristala, možemo pretpostaviti da se radi o mineralu etringitu (trikalcij aluminat trisulfat) - $\mathrm{Al}_{2} \mathrm{O}_{3} 3 \mathrm{C}_{2} \mathrm{SO}_{4} 32 \mathrm{H}_{2} \mathrm{O}$, koji je nastao kao reakcija kalcij aluminijskog hidrata $3 \mathrm{CaO} \mathrm{Al}_{2} \mathrm{O}_{3} \mathrm{Ca}(\mathrm{OH})_{2} 12 \mathrm{H}_{2} \mathrm{O}$ i otopljenih sulfata u vodi. Iz morfološke strukture uočenih kristala na nekim prijelomnim površinama proučavanih uzoraka, jasno je da se radi o sporom rastu. Kristali brzog rasta su tanki - kao niti, a kristali sporog rasta su deblji. Laboratorijskim analizama uzoraka nije 
dovoljno sigurno dokazana prisutnost minerala etringita. Izvršen je mikroskopski pregled i kemijska analiza postupkom EDS koji nije tako siguran kao rendgenska difrakcija (XRD) [13]. Na prijelomnim površinama uzoraka utvrđene su veoma male količine etringita. Metodom rendgenske difrakcije nažalost nije moguće identificirati etringit ako se javlja u vrlo malim količinama [14].

\subsection{Proračun temperaturnih opterećenja šupljih opečnih blokova}

Geometrijski model za proračun prikazan je na slici 9a), a model s mrežom konačnih elemenata na slici 9b).

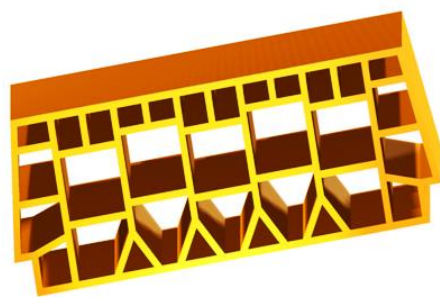

a)

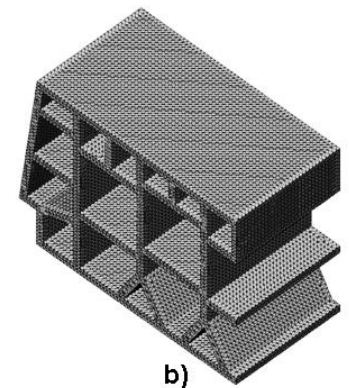

b)

Slika 9a) - Pogled na izrađen geometrijski model šupljeg opečnog bloka; b) Pogled na mrežu elemenata proučavanog modela

U proračunima je uzeto u obzir da su šuplji opečni blokovi na stranicama kruto upregnuti u nosače, a na gornjoj i donjoj plohi slobodno. U plohama simetrije uzeti su u obzir rubni uvjeti, kao što je to prikazano na slici 10.

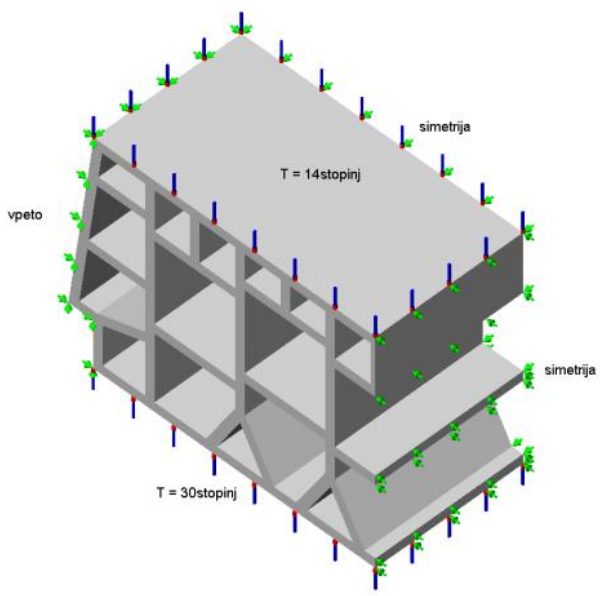

\section{Slika 10 - Razmatrani rubni uvjeti i temperaturna opterećenja}

Rezultati proračuna utjecaja temperaturnih opterećenja dani su za tri primera koji odgovaraju izmjerenim modulima elastičnosti i izmjerenim vlačnim čvrstoćama materijala. Rezultati proračuna za uzorke A1, B2 i C3 dani su u tablici 5.

Tablica 5 - Proračun utjecaja temperature

\begin{tabular}{|c|c|c|c|c|c|c|}
\hline uzorak & $\sigma_{x}(\mathrm{MPa})$ & $\sigma_{z}(\mathrm{MPa})$ & $\sigma_{\text {pr }}(\mathrm{MPa})$ & $\mathrm{R}_{\mathrm{m}}(\mathrm{MPa})$ & $\mathrm{R}_{\mathrm{m}}{ }^{*}(\mathrm{MPa})$ & $\mathrm{E}(\mathrm{MPa})$ \\
\hline $\mathrm{A} 1$ & 3,9984 & 3,5001 & 3,6695 & 7,90 & 6,80 & 22203 \\
\hline $\mathrm{B} 2$ & 7,9724 & 6,9788 & 7,3166 & 13,80 & 13,60 & 44270 \\
\hline $\mathrm{C} 3$ & 7,3617 & 6,4442 & 6,7561 & 8,50 & 6,90 & 40879 \\
\hline
\end{tabular}


Rezultati proračuna temperaturnih opterećenja za uzorak A1 pokazuju da se normalna naprezanja $\sigma_{x}$ pojavljuju kao vlačna na donjoj strani. Na slikama 11a) i 11b) prikazana su mjesta na kojima dostižu najveću vrijednost, ali koja je manja od obje vrijednosti na uzorcima izmjerenih vlačnih čvrstoća.

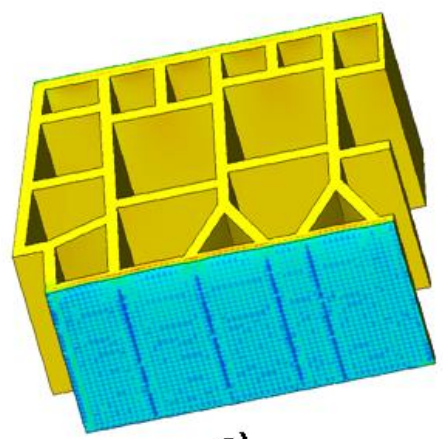

a)

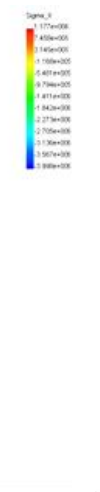

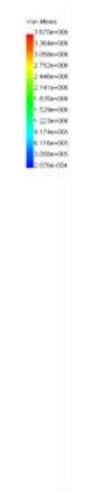

\section{Slika 11a) - Raspored normalnih naprezanja $\sigma_{x}$ po donjoj strani šupljeg opečnog bloka; b) Usporedna naprezanja u izometričnom pogledu}

Promjenjiva naprezanja $\sigma_{\mathrm{pr}}$ (von Mises stress) su manji od izmjerenih vlačnih čvrstoća, a prikazani su na slici 11b). Pomaci Uy i rezultantna pomicanja prikazana su na slikama 12a) i 12b). Vrijednosti su dane u milimetrima i male su.
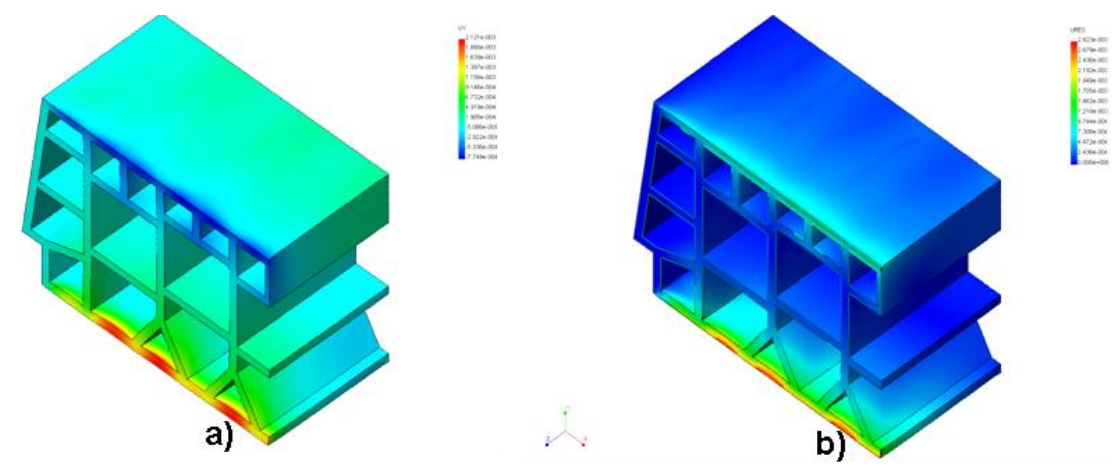

\section{Slika 12a) - Pomicanja $U_{y}$ šupljeg opečnog bloka u izometričkom pogledu (u mm); b) Rezultantna pomicanja šupljeg opečnog bloka u izometričkom pogledu (u mm )}

Rezultati za uzorak B2 prikazuju veće normalna i usporedna naprezanja, ali koji su manji od izmjerenih vlačnih čvrstoća. Na slikama 13a), 13b), 14a) i 14b) dana su pomicanja koja pokazuju mjesta mogućih pojava većih vrijednosti normalnih i usporednih naprezanja i zbog relativnih pomicanja.

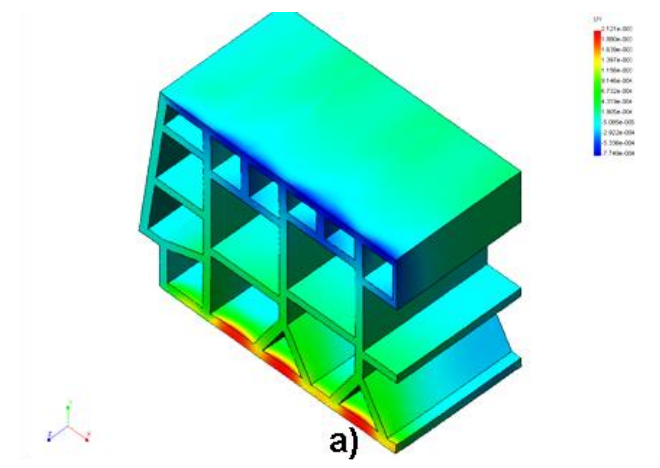

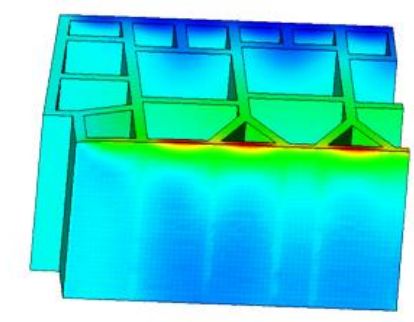

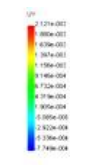

b) 
Slika 13 a) - Pomicanja Uy šupljeg opečnog bloka u izomeričnom pogledu (u mm); b) Tijek pomicanja $U_{y}$ na donjoj strani šupljeg opečnog bloka (u mm)

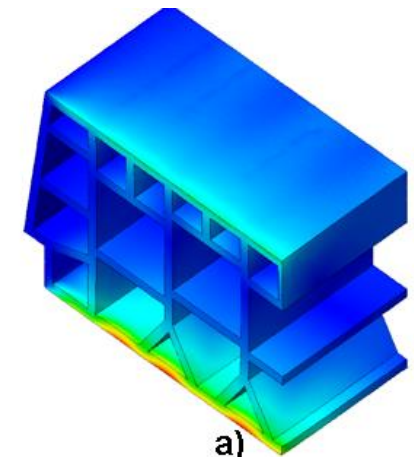

a)

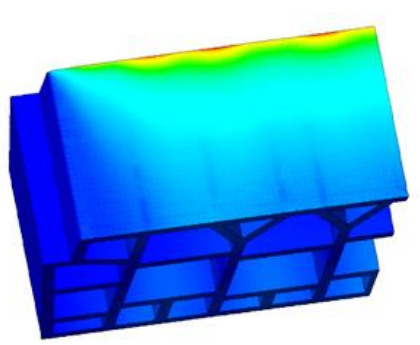

b)

Slika 14a) - Rezultantna pomicanja šupljeg opečnog bloka u izometričkom pogledu (u mm); b) Prikaz rezultantnih pomicanja na donjoj strani šupljeg opečnog bloka (u mm)

Rezultati za uzorak C3 najslabiji su glede izmjerene vlačne čvrstoće. Na slikama 15a) i 15b) prikazana su normalna i usporedna naprezanja na donjoj strani, gdje su se zapravo i pojavila oštećenja šupljeg opečnog bloka. Raspored pomicanja koji je dan na slikama 16a) i 16b) potvrđuje takvo stanje.
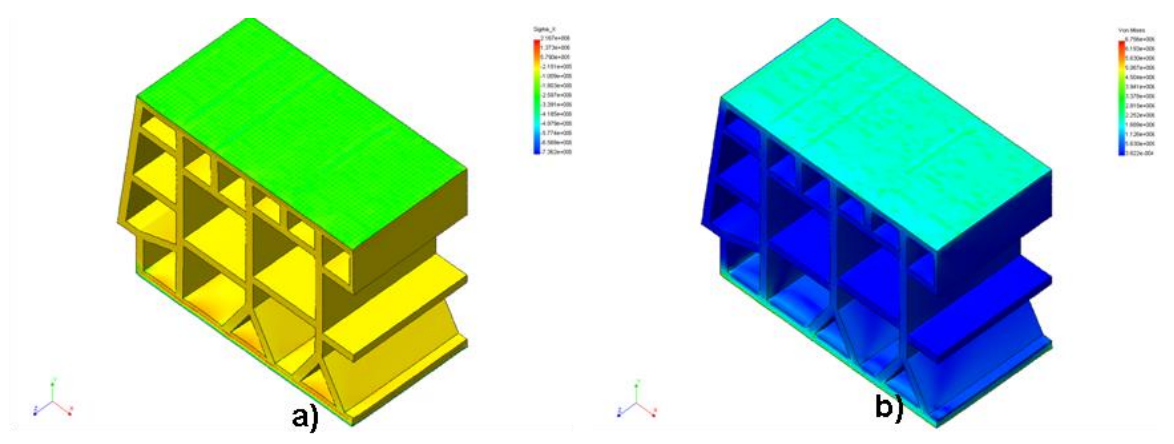

Slika 15a) - Raspored normalnih naprezanja $\sigma_{x} u$ izometričkom pogledu; b) Usporedna naprezanja u izometričkom pogledu šupljeg opečnog bloka
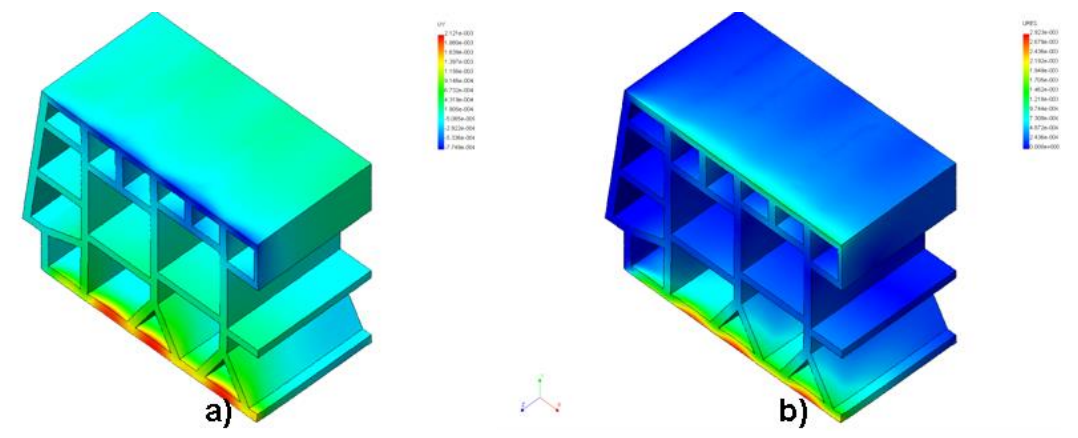

Slika 16a) - Pomicanja Uy šupljeg opečnog bloka u izometričkom pogledu (u mm); b) Rezultatska pomicanja šupljeg opečnog bloka u izometričkom pogledu (u mm) 
Na slikama 17a) i 17b) prikazan je raspored faktora sigurnosti na modelu s obzirom na Misesovu hipotezu razaranja. Slika 17a) pokazuje da je u pretežnom dijelu donje strane faktor sigurnosti manji od 2 (površina koja je na slici obojena crveno), s obzirom na vrijednost vlačne čvrstoće 8,05 MPa. Još slabije stanje pokazuje slika $17 b)$, gde je praktično čitava donja strana crveno obojena. Iz rezultata koji su dani u tablici 2 također vidimo da su usporedna naprezanja veoma blizu vlačnoj čvrstoći (6,90 MPa).

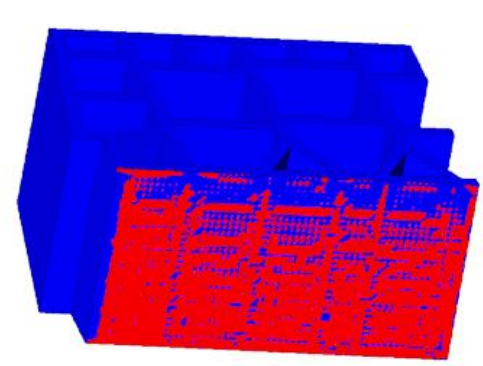

a)

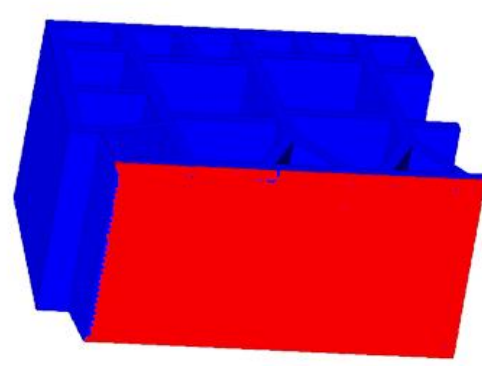

b)

\section{Slika 17a) - Raspored prekoračenja faktora sigurnosti (2.00) po donjoj strani šupljeg opečnog bloka $\left(\sigma_{\mathrm{m}}=8.50 \mathrm{MPa}\right) ;$ b) Raspored pekoračenja faktora sigunosti (2.00) po donjoj strani šupljeg opečnog bloka $\left(\sigma_{\mathrm{m}}=6.90 \mathrm{Mpa}\right)$}

\section{Zaključci}

Temeljem prikazanih rezultata proračuna toplinskih opterećenja na šuplje opečne blokove koji su element stropne konstrukcije, zaključujemo da su vlačna naprezanja zbog temperaturnih opterećenja mogli biti glavnim uzrokom oštećenjima na šupljim opečnim blokovima. Nije moguće tvrditi da je to jedini uzrok. Uzrokom može biti i mineralni sastav materijala od kojega su izrađeni blokovi, a i utjecaj vlage. Iskristalizirana sol nastala je u elementima šupljeg opečnog bloka kao naknadna reakcija uzrokovana uporabom objekta. EDS analizom utvrđena je prisutnost kemijskih elemenata S i Al, a i morfologija kristala utvrđena elektronskim mikroskopom daje vrlo veliku vjerojatnost da je riječ o prisutnosti minerala etringita. Potrebno je upozoriti da su uvjeti za kristalizaciju bili na objektu osigurani tek poslije dvije godine uporabe objekta. Zbog aktivnog centralnog zagrijavanja objekta i difuzije vodene pare iz zraka iz zagrijavanih prostorija kroz strop u nezagrijavane prostorije, u materijalu se povećala vlažnost i stvoreni su uvjeti za rast kristala.

\section{Literatura}

[1] Nandi, A.: Effect of Physico - Chemical Factors on the Desintegration Behavior of Calcareous Shale, Environmental \& Engineering Geoscience. 15, 2009.

[2] Cultrone, G.: Influence of mineralogy and firing temperature on the porosity of bricks, Journal of the European Ceramic Society. 24, 2004.

[3] Fernandes, F.M.; Laurenco, P.B.; Castro, F.: Ancient Clay Bricks: Manufacture and Properties, Materials, Technologies and Practice in Historic Heritage Structures, 2009.

[4] Cultrone, G.: Mineralogical and physical characterization of the brick used in the construction of the "Triangonal Bastion", Riga (Latvia), Applied Clay Science, 28, 2005.

[5] Abu Bakar, B.H.; Wan Ibrahim, M.H.; Megat Johari, M.A.: Durability of fired clay brick masonry wal due to salt attack, International Journal of Integrated Engineering, Vol.1, № 2, 2009. 
[6] Van Hees, R.P.J.; Wijfels, T.J.; Van der Klugt, L.J.A.R.: Thaumasite swelling in historic mortars: field observations and laboratory research, Cement \& Concrete Composites, Vol. 25, 2003.

[7] Larbi, J.A.: Microscopy Applied to the Diagnosis of the Deterioration of Brick Masonry, Journal of Construction and Building Material, Vol. 18, 2004.

[8] Niragik, D.: Effect of Sulpahate Attack on Properties of Concrete - A Rewiew, International Journal of Emerging Trends in Engineering and Development, Issue 3, Vol. 1, 2013.

[9] Santanan, M.; Cohen, M.D.; Olek, J.: Mechanism of Sulphate Attack: A Fresh Look Part 1: Summary, Cement and Concrete Composite, Vol. 25, 2002.

[10] Barić. L.; Tajder. M.: Mikrofiziografija petrogenih minerala, Školska knjiga, Zagreb, 1976.

[11] Cosmos/Designstar, User's Guide, Version 3.0 (SRAC), Michigan, 2000.

[12] Shackelford. J.F.: Introduction to materials science for engineers, Prentice Hall, Upper Saddle River, New Jersey, 1996.

[13] Mehta, P.K.: Scanning electron micrographic studies of ettringite formation, Pergamon Press USA, Cement and concrete research, Vol.6, 1976.

[14] Ramadan, E.O.: Experimental and theoretical study of delayed ettringite damage in concrete, UMI Number: 9967966

[15] Collepardi M.: Degradation and restoration of masonry walls of historical buildings, Materials and Structures, Vol. 23, 1990. 